\title{
Short-Dated Products Marketing Strategies, Analytic Netwok Process Approach
}

\author{
$1^{\text {st }}$ Muhamad Taqi \\ Dep. Accounting \\ University of Sultan Ageng \\ Tirtayasa \\ Serang Banten, Indonesia \\ Indonesia Center of Excellence \\ For Food Security \\ muhamad.taqi@yahoo.com \\ $4^{\text {th }}$ Sabaruddinsah \\ Sabaruddinsah \\ Dep. Acounting \\ University of Sultan Ageng \\ Tirtayasa \\ Indonesia Center of Excellence \\ For Food Security \\ Serang Banten, Indonesia \\ sabaruddin77@gmail.com
}

\author{
$2^{\text {nd }}$ Tubagus Ismal \\ Dep. Accounting \\ University of Sultan Ageng \\ Tirtayasa \\ Indonesia Center of Excellence \\ For Food Security (I-CEFORY) \\ (Local Food Innovation) \\ Serang Banten, Indonesia \\ adeismail73@gmail.com
}

\author{
$3^{\text {rd }}$ Meutia Meutia \\ Dep. Agriculture \\ University of Sultan Ageng \\ Tirtayasa \\ Indonesia Center of Excellence \\ For Food Security (I-CEFORY) \\ (Local Food Innovation) \\ Serang Banten, Indonesia \\ Tia_almer@yahoo.com
}

\begin{abstract}
The adverse impact if SMEs do not improve their marketing strategy is the stagnation of sales. This study discussed the proper strategy of short-dated products. This discussion related to the formulation of problems, solutions and strategies which found that the main problem of these short-dated products is the raw material of coconut milk which caused the products to expire quickly. The solution was not by substituting raw material of coconut milk with milk, but producers only needed to meet the consumers (markets) demands. The problem was then divided into 3 categories, namely price, location and promotion. This problem certainly had sub-problems and there was a solution. The results of all these sub-problems were summarized with 3 marketing strategy choices by citing the Porter marketing technique namely generic strategic.
\end{abstract}

Keywords: Analytical Network Process (ANP), Short-Dated Products Marketing Strategy, Expert Judgement

\section{INTRODUCTION}

A developed country is a country that has a minimum employer ratio of $2 \%$ of the total population (McCelland \& Winter, 1969). This is supported by several studies which found that a poor country was not due to lack of resources, but ue to lack of good entrepreneurs (Gupta \& Srinivasan, 1992; Ismail, 2016; Meutia, 2017).

It is not surprising that entrepreneurs or SMEs have a role as engines of economic growth, to minimize economic inequalities and even act as change agent innovators (Azim, 2011; Ismail and Ghozali, 2015). Due to this facr, of course, Indonesia needs to reach and utilize the existing great potential to develop SMEs. One of the greatest potential is the outcomes of fisheries resources.

Banten Region is one of the sea lanes with the potential for fisheries, since it is located in the Sunda Strait, and is one of the crossing lines that connects Australia, New Zealand and the Southeast Asian region. It is reasonable for the marine and fisheries sectors to be expected as the foundation of the economy in the future.

\section{LITERATURE REVIEW}

A. Analysis of the Aspects of Local Processed Food Products of Milkfish Satay

Milkfish satay is a protein-based local processed food. The disadvantages of milkfish are the meat which smells of mud and its thorns which are not easy to clean. This causes milkfish to be less practical to be consumed mainly by children and the elderly. For this reason, an effort is needed in the utilization of milkfish, one of which is by processing the milkfish into products that have value added to overcome the problem.

B. SME Development Function

The importance of the growth and development of SMEs in society is not merely a 'tool' to make changes and 
improvements in the quality and quantity of the economic wheel of society, but entrepreneurship is also proven to play a significant role in realizing the quality of the people and nations to become developed countries (Frinces , 2010; Ismail et al., 2018)

The evidence of this is explained by Peter F. Drucker (1994) in his book entitled Innovation and Entrepreneurship which found that entrepreneurs (SMEs) had a large role in creating employment in the United States (US) in the period of 1965-1985, while at that time the condition the US economy was so disadvantaged that Drucker referred to as the - no growth economy.

Drucker said, "In no other peace time period has the United States created as many new jobs, whether measured in percentage or in absolute number". Based on that, the existence of SMEs or employers is very important in the progress or regress of a country. There is even agreement among all nations, regardless of their "welfare" status, that entrepreneurship has an important role in the country's economic development, in the context of broader "development" (Hisrich \& Peters, 1998).

According to the observations above, the movement for the development of SMEs in Indonesia must continue to be carried out, considering its very large contribution to the economy of a country which also able to reduce unemployment and poverty.

\section{Marketing Performance}

Ferdinand (2000) states that marketing performance is a factor often used to measure the impact of strategies implemented by the company. The company's strategy is always directed at producing good marketing performance and good financial performance (Ismail et al., 2019.

\section{STUDY METHOD}

A. Data Collection Technique

In-depth interview with the informant

In interactiong with the subjects, the researcher is expected to provide a more complete understanding of study through interviews using recording devices, notes, and observation technique as participants to directly see behaviors associated with observed phenomena (Sanders, 1982, Saerang, 2001). Researchers interact directly in the field to observe the subjects under study for some time until the researcher certainly feels that the data collected are sufficient to explain the situation that occurred.

\section{B. Population and Samples}

The selection of respondents in this study was conducted by considering the respondents' understanding of the marketing strategy of satay milkfish product. The number of respondents in this study consisted of three marketing strategy experts/observers based on competency consideration. Valid respondents as the requirement in ANP were that masters or experts in their fields. Therefore, the respondents selected in this survey were marketing strategy experts/researchers and practitioners involved in the world of milkfish satay culinary business.

\section{Analysis Tools}

After the data were obtained, the researcher used the Analytical Network Process (ANP) software and processed them using "Super Decision 3.0" software to make effective marketing model in marketing satay milkfish at Banten Province. The general network structure was used.

\section{SYNTHESIS RESULTS ANALYSIS}

The results obtained by a systematic consensus from experts (observers) regarding the marketing strategy of shortdated products included criteria and alternative strategies. In the picture below, the priorities of the problems criteria that occurred in the marketing of short-dated products businesses were divided into $4 \mathrm{P}$, namely Product, Price, Place and Promotion. From the criteria of the problem, there was a priority problem of Product of $44.12 \%$. This meant that experts or observers ensured that the main problem of milkfish products marketing was the product strategy itself.

The next positions of importance were Price of $20.85 \%$, Place of $20.29 \%$ and the last interest was Promotion of $0.74 \%$. Importance level calculation was taken from the means (geometric mean) of the answers from experts or observers of short-dated products SMEs namely milkfish satay.

The value of the rater agreement in the figure above was $\mathrm{W}=0.369565$ which meant that $36.96 \%$ (rounding) of respondents agreed that the main problem in short-dated products marketing was Product. 
Those findings can be concluded that according to experts, the marketing problem related to prices was that milkfish satay product was a typical premium product in Banten, so it was unethical to reduce prices even though there were high purchases. In addition, milkfish satay SMEs also did not make price differentiation. For example to make a variety of flavor of the satay products, it was better not to make a difference in price (still 1 price even though the flavor, raw material and additional variations of the satay were differentiated). The results of the rater agreement of the $4 \mathrm{P}$ criteria in the category of price problem was $\mathrm{W}=0.33333$, which meanr that $33.33 \%$ of respondents agreed that the main problem of marketing strategies related to price was taht SMEs tended to imitate the prices of competitors.

The third order of importance of the marketing strategy problem was "Location Problem". This criterion was divided into 4 main observations. One priority of the main problem was the less strategic location of the SMEs of $37.36 \%$. This meant that Milkfish satay SMEs should choose easily accessible business locations for tourists, considering that the milkfish satay product was a typical processed product of Banten Province.

The next order of importance was the lack of parking lot availability of $22 \%$, the same locations as competitors of $17.8 \%$ and did not have a website address with the official domain (.com and similar, not BlogSpot) of $12.74 \%$.

According to experts and observers, there was a connecting line on the problem of location that there was no need for a domain or an official website online, SMEs only needed to focus on locations that were quite easy to reach and those locations had parking lots. The result of the rater agreement of the $4 \mathrm{P}$ criteria for the location problem category was $\mathrm{W}=0.458564$, which meant that $45.86 \%$ of observers or experts agreed that the main problem of the location was strategy or ease of access and having an official address online on the website was not so important.

The last problem of marketing strategy with the $4 \mathrm{P}$ category was the promotion problem. This criterion was divided into 6 main sub-problems. The three sub-priority areas were had not had salespeople such as agents and resellers of $26.7 \%$. Had not performed paid online advertising or used the services of grab food and go-food of $19.91 \%$. had not created a new branch of $14.43 \%$.

The 3 other sub-areas that were not the main priorities were radio promotion method and traditional advertisements of $13.27 \%$. Did not created franchise of $10.38 \%$ and promotion campaign that had not used printed brochures as a promotional media was not the main highlight of $8.945 \%$.

According to observers or experts, the findings of promotion problems of printed media technique, franchises and even radio ads were very ineffective and not the main problem. The franchise was not a major problem considering the difficulty of duplicating the uniformity of the taste of processed milkfish satay products so that the franchise technique was not a choice of problems that could boost the sale of milkfish satay product.

The result of the rater agreement of the 4P criteria for the category of promotion problem was $\mathrm{W}=0.490486$. This meant that observers agreed that $49.05 \%$ stated that the main promotion issue was did not have salespeople such as agents and resellers, had not registered go-food and grab food and paid online advertising plus had not had a new branch as the 3 main problem points in promotion.

In detail the description of the results of the solutions synthesis of product, price, place and promotion was the same as the figure of synthesis problem. The product solution was usually not always in line with the importance of the problem. It is due to the solution given is very close to the connection of short-term and easiest problems solving. Thus, the main problem not always be solved with a solution that is in line with the main problem, and this has been discussed as well.

For example, solutions for SME products should be consumer oriented (based on market demand for products, shapes and flavors) rather than trying to substitute raw materials of coconut milk with milk. Whereas the main problem discussed earlier was a product that had short expiration date. There was a major problem with the criterion of the "price problem" with the priority level of completion of "price solution".

The difference in interesting finding regarding location solution compared to location problem, namely having the official address of the website was a more important priority than moving locations so that they didn't coincide with other competitors. 
Whereas previously it was discussed that same location as the competitors problem was more important to solve rather than not having an official website. This clearly showed that the solution shown was the most important short-term step and could be immediately realized. The difference between the main problem and the solution was also on the use of radio advertising services, endorse figures or local artists. Whereas, previously the problem of did not utilize radio advertising was a very insignificant problem. However, in reality the solution stated the opposite, this might happen considering that it was very easy to advertise on radio and used artist endorse rather than adding new branches.

The rater agreement on all results of the product solution synthesis of strategy, price, location and promotion were fairly high (with a range of product solution of $\mathrm{W}$ $=0.369565$, price solution of $\mathrm{W}=0.361111$, location solution of $\mathrm{W}=0.522222$, promotion solution of $\mathrm{W}=0.274854$ ) which meant that the respondents agreed that the solution of the four existing problems was at least $27.48 \%$.

The last finding when discussing the criteria of the problem and the solution must be the determination of the strategy. The following is the agreement from three observers or experts.

The respondents stated that the most appropriate strategy to solve the 4P problem and its sub-criteria was segmentation technique. The segmentation strategy or focus was oriented to the segmentation of certain consumers or markets.

Milkfish satay is a typical Banten products intended for consumers who are on vacation, visiting, special ceremonial events or agencies and all ceremonial forms that have relevance to the demographic location of Banten.

The priority value of the marketing strategy through segmentation was $41.4 \%$. Then it was followed by a differentiation marketing strategy of $27.45 \%$ and cost leadership of $23.65 \%$. This finding proved that cost leadership or low cost strategy was not strong enough to be a strategy considering that milkfish satay wsa exclusive product due to the difficult production process and high quality of raw materials. The differentiation was not exactly the proper strategy because the product variations, flavors, types, shapes and other uniqueness were considered inappropriate to boost sales value in the marketing strategy of milkfish satay business.

The connecting line in this study explained that the value of the rater agreement was $\mathrm{W}=0.083333$, which meant that observers and experts had a low agreement related to the three choices of strategies above of only $8.33 \%$. This is very possible because the strategy of differentiation is very likely to be the market leader if the types of milkfish processed products (such as shredded meat, meatball, nugget, sausages and skin chips) are able to compensate for sales or become complementary to milkfish satay product.

The low cost strategy was also very likely to be able to dominate the market. This can occur if the low price strategy, price discount is focused on consumers who order during ceremonial events.

rThe final discussion in the Analytical Network Process was that the inconsistency mean value of 0.031012 (consistency reached 96.9\%), which meant that respondents had a level of truth that would consistently answer priority levels (not ambiguous/doubtful/hesitate) and the indepth interview process was done through good stages without intervention from the author and enumerator.

\section{CONCLUSIONS}

This study had many findings related to difficulties, solutions and even strategies to overcome for MSEs that were engaged in short-dated semi-wet processed products such as milkfish satay and their processed products. It was found that the main problems of 4P marketing strategy in sequence were product, price, place and promotion. The product problem was regading the raw material of coconut milk that produced short-dated products that expired 1 to 3 days. The main solution was not to replace coconut milk with substitute raw material such as pure milk which could provide longer durability. The easiest solution was that SMEs should maintain product quality and quantity according to market demands.

The second problem in price criteria was that SMEs that always imitated the prices of other competitors with no courage to give discounts or price promotions. The solution to this price problem was valued based on the order of priority.

The third problem in location criteria was that SMEs had less strategic locations 
and the solution to the main problem was not by renting new location, but providing good parking before renting a strategic place.

The fourth problem in promotion criteria was that the importance of SMEs to have an agent and reseller scheme, of course the solution was along with the importance level of this problem.

The value of agreement from observers and experts was stated to be quite high, except that on the alternative strategy criteria of the porters, respondents had a very low level of agreement. This meant that any marketing strategy was very possible to use. Meanwhile, the value of consistency of all respondents was considered quite high.

\section{REFERENCES}

[1] Ascarya. (2010). The Development Of Islamic Financial System In Indonesia And The Way Forward. paper to be published as Occasional Paper, Bank Indonesia.

[2] Ascarya, \& Yumanita, D. (2010). Determinan dan Persistensi Margin Perbankan Konvensional dan Syariah di Indonesia. working paper series No.WP/10/04. Pusat Pendidikan dan Studi Kebanksentralan Bank Indonesia.

[3] Azim, M. (2011). Entrepreneurship Development in Bangladesh, 1st ed.,. Dhaka: UGC.

[4] Drucker, P. (1994). Inovasi dan Kewirausahaan: Praktek dan DasarDasar. Jakarta: Airlangga, (Terjemahan).

[5] Ferdinand, A. (2000). Manajemen Pemasaran :Sebuah Pendekatan Strategy. Research Paper Serie.No. 01 Program Magister Manajemen Universitas Diponegoro (Maret).

[6] Frinces, Z. (2010). Pentingnya Profesi Wirausaha di Indonesia. Jurnal Ekonomi \& Pendidikan, Volume 7 Nomor 1, April 2010. 34-57.

[7] Fristia, V. F., \& Navastara, A. (2014). Faktor Penyebab Belum Berkembangnya Industri Kecil Batik Desa Kenongo Kecamatan TulunganSidoarjo. Jurnal Teknik ITS Vol 3 No 2.

[8] Gupta, G., \& Srinivasan, N. (1992). Entrepreneurial Development. New Delhi: Sultan Chand \& Sons.

[9] Hamid, E., \& Susilo, Y. (2011). Strategi Pengembangan UMKM di Provinsi Daerah Istimewa Yogyakarta. Jurnal Ekonomi Pembangunan di Provinsi Daerah Istimewa Yogyakarta.
[10] Hisrich, R., \& Peters, M. (1998). Entrepreneurship (4th edn.). Boston: Irwin McGraw-Hill.

[11] Ismail, T. (2016), "Culture control, capability and performance: Evidence from creativeindustries in Indonesia", Asian Review of Accounting, Vol. 24 (2), pp. 171-184.

[12] Ismail, T. and Ghozali, I. (2015), "Control system, strategy and learning", Academy of Strategic Management Journal, Vol. 14 (1), pp. 58-72.

[13] Ismail, T. Meutia, Bokhori, A. Fajri, E. (2018) Building Innovation Capability Through Triple Helix Model Sinergy To Improve SME's Marketing Performance. International Journal of Civil Engineering and Technology. Vol. 9 (7). Pp. 1403-1412,

[14] Ismail, T. Meutia dan Ummi, N. (2019) Enabling management control in improving the performance of SMEs. Management Science Letter. Vol. 9 (10) Pp. 1823-1832.

[15] McCelland, D., \& Winter, D. (1969). Motivating Economic Achievement. New York: Free Press.

[16] Meutia (2017). Proactive attitude and organizational performance. International Journal of Economic Perspetive. Vol. 11 (1).

[17] Neuman, S. B., \& Dickinson, D. (2003). Handbook of Early Literaty Research. New York London: The Guilford Press.

[18] Porter, M. E. (1980). Competitive Strategy Techniques for Analyzing Industries and Competitors with a New Introduction. The Free Press.

[19] Rusydiana, A. S. (2013). Analytic Network Process: Pengantar dan Teori. Bogor: SMART Publishing.

[20] Rusydiana, A. S. (2015). Aplikasi Metode Analytic Network Process (ANP) dalam Riset Ekonomi \& Keuangan Islam . Bogor: SMART Publishing.

[21] Rusydiana, A. S., \& Devi, A. (2013). Ebook Analytical Network Process Pengantar Teori dan Apalikasi. Bogor: Smart Publishing.

[22] Rusyidiana, A. S. (2017). Analytic Hierarcy \& Network Process (AHPANP) Part II Application. Tasikmalaya: Smart Publishing.

[23] Saaty, T. (2005). Decision Making for Leader: The ANalytical Hierarchy Prosess For Decision in Complex 
World. Prentice Hall Coy. Ltd. : Pittsburgh.

[24] Satria, D. (2011). Strategi Pengembangan Industri Kreatif Untuk Meningkatkan Daya Saing Pelaku Ekonomi Lokal. Jurnal Aplikasi Manajemen Vol 9, No 1.

[25] Sriyana, J. (2010). Strategi Pengembangan Usaha Kecil dan Menengah (UKM): Studi Kasus di Kabupaten Bantul. Simposium nasional.

[26] Susanti, E. A. (2013). Pengembangan Ekonomi Lokal Dalam Sektor Pertanian (Studi pada Kecamatan Pagelaran Kabupaten Malang). Jurnal Administrasi Publik.

[27] Syahza, A. (2003). Analisis ekonomi usaha tani hortikultura sebagai komoditi unggulan agribisnis di Kabupaten Pelalawan, Propinsi Riau. Perspektif VIII (01). 